\title{
VOLTAIRE, ROUSSEAU E O CRISTIANISMO: HISTÓRIA E PODER
}

\author{
Otacílio Gomes da Silva Neto ${ }^{1}$
}

\begin{abstract}
Resumo:
A história do cristianismo foi objeto de investigação entre os pensadores do século XVIII. Nesse trabalho, o nosso objetivo é o de revisar as relações entre o cristianismo e o poder, a partir de uma análise comparativa das ideias de Voltaire e Rousseau em seu domínio histórico. O estudo foi realizado a partir de uma pesquisa bibliográfica por meio de uma abordagem filosófica que envolve escritos desses dois pensadores da filosofia. Em Voltaire, a nossa análise inclui uma investigação sobre Jesus Cristo enquanto personagem histórico bem como uma "genealogia" do cristianismo, conforme as obras: "O túmulo do fanatismo" (1736), "Tratado sobre a tolerância" (1763) e "Catecismo do homem honesto" (1763). Quanto a Rousseau, buscamos interpretar a sua abordagem histórica a respeito do cristianismo e suas conexões com a política. A nossa investigação baseia-se nas obras: "Resposta ao rei da Polônia" (1751), o capítulo sobre a "Religião civil" em "Do Contrato Social" (1762) e "Cartas escritas da montanha" (1764). Os resultados do trabalho pontuam não apenas semelhanças e diferenças entre Voltaire e Rousseau, quanto à tensão entre cristianismo e poder em seu domínio histórico, mas também oferecem esclarecimentos que direcionam para a necessária defesa de um Estado laico.
\end{abstract}

Palavras-chave: Voltaire. Rousseau. Cristianismo. História. Política.

\section{VOLTAIRE AND ROUSSEAU ON CHRISTIANITY: HISTORY AND POWER}

\begin{abstract}
:
The history of Christianity was a prevalent subject among $18^{\text {th }}$ century philosophers. This article presents a historical perspective of the relationship between Christianity and power based on a comparative analysis of the ideas of Voltaire and Rousseau. Bibliographic research was undertaken using a philosophical approach to their works. This study examines Voltaire's inquiry into Jesus Christ as a historical figure and a "genealogy" of Christianity in three of his works: Tumbeau du fanatisme (1736), Traité sur la tolérance (1763), and Catéchisme de l'honnête homme (1763). Regarding Rousseau, this study interprets his historical approach to the connections between Christianity and politics based on the following works: Sur la Réponse qui a été faite à son Discours (1751), the chapter entitled "Civil Religion" in Du Contract social (1762), and Lettres écrites de la montagne (1764). Not only do the findings of this inquiry reveal the similarities and differences between the thoughts of Voltaire and Rousseau and the historical tensions between Christianity and power, the findings also point toward a fundamental defense of a secular state.
\end{abstract}

Keywords: Voltaire. Rousseau. Christianity. History. Politics.

\section{Introdução}

A competição pelo poder político entre a esfera religiosa de vocação cristã e as orientações secularizadas no interior das sociedades ocidentais é de longa data. Encontramos

1 Professor do Departamento de filosofia (UEPB). Doutor em filosofia na área de concentração em Ética e Filosofia Política pelo Programa Integrado de Doutorado em Filosofia - UFPE-UFPB-UFRN. Membro do grupo de estudos de Filosofia da Religião (UEPB/CNPQ) e da Associação Brasileira de Estudos do Século XVIII (ABES18). E-mail: otacilio.uepb@ hotmail.com. 
na história da nossa era várias vozes que se levantaram contra a ganância dos líderes cristãos sobre os domínios temporais. O assédio de grupos cristãos relativo à autonomia dos espaços seculares pela via do controle político despertou em nós o interesse em investigar o assunto. A nossa hipótese parte do princípio de que a influência do cristianismo enquanto alinhado ao poder político gera instabilidades, abusos e desmandos sobre a sociedade. Destacamos o fato de que essa influência faz parte não apenas do passado, mas também dos dias atuais.

Afinal, quem imaginaria que passados alguns séculos de valorização de algumas ideias do Século das Luzes, como a tolerância, iríamos, nos tempos de hoje, ter que revisar algo tão evidente como a importância da liberdade de culto? Nesse aspecto, o Estado deve ser cristão e banir de forma intolerante todos aqueles que professam outras crenças e outros não crentes de seus domínios? Devemos alterar os costumes laicos na sociedade para torná-los cristãos porque determinadas igrejas cristãs nos obrigam?

Para esse trabalho, o nosso escopo é o de investigar a história do cristianismo e os seus vínculos com o poder político, tendo por base as ideias de Voltaire e Rousseau². Ele está organizado em três partes. Na primeira, problematizaremos os vínculos entre Voltaire e Rousseau e o cristianismo. Na segunda, investigaremos as razões pelas quais Voltaire questiona historicamente a continuidade entre a tradição judaica e a cristã, por meio de Jesus Cristo, já que, provavelmente Jesus não teve a intenção de formar nenhuma igreja. A terceira parte será dedicada a Rousseau e sua análise histórica do cristianismo enquanto inserido nos domínios da política.

\section{I}

As ideias de Voltaire realçam a necessidade de a humanidade superar os conflitos religiosos, sobretudo aqueles advindos do cristianismo católico no século XVIII. Analisando a história da humanidade, esse pensador francês destaca o desenvolvimento histórico do cristianismo amalgamado a momentos degradantes da civilização. A sua investigação que une a história das civilizações à das religiões (SOUZA, 2001) leva-o à conclusão de que as histórias e narrativas mitológicas do judaísmo e, posteriormente, do cristianismo, têm

2 Utilizaremos em rodapé as referências das "Obras Completas" (O. C.) de Rousseau e Voltaire publicadas pela Gallimard. Para o apoio às referências diretas da fonte em outro idioma, utilizaremos em rodapé a indicação como tradução livre.

\begin{tabular}{|c|c|c|c|c|}
\hline Revista Q Didectus & Ano 8 & n. 15 & Agosto - Dezembro 2019 & p. $232-252$ \\
\hline
\end{tabular}


pouquíssima originalidade, conforme o próprio Voltaire (2006) nos apresenta na obra: “O túmulo do fanatismo". O judaísmo e o cristianismo são o foco principal dessa obra.

Nela, Voltaire insiste que o judaísmo readaptou lendas de outros povos mais antigos, criando outras tantas narrativas insensatas e bárbaras. Os judeus são caricaturados como uma horda de ladrões, pequeno povo escravizado e grosseiro ${ }^{3}$. Foi dele que nasceu Jesus, entre narrativas contraditórias e verossímeis. Nada garante, para Voltaire, que Jesus tenha fundado o cristianismo. Esta religião originada em meio à "populaça", conseguiu se desenvolver a partir de relatos verossímeis envolvendo histórias de mártires, difíceis de acreditar, na sua ótica. Em meio a conchaves, intrigas e disputas teológicas sanguinárias, o cristianismo ganhou força e chegou ao que era, no Século das Luzes. Para Voltaire, conforme Ruzza (2012), a defesa do deísmo ${ }^{4}$ era necessária para superar a superstição, o fanatismo e a intolerância promovidos pelos conflitos provocados por seitas como a de determinados cristãos.

Rousseau foi relativamente receptivo para com o cristianismo. A rigor, não houve em seus escritos uma superação dessa religião em favor do ateísmo ou do deísmo, por exemplo. Contudo, não há unanimidade entre os estudiosos sobre a continuidade ou não entre Rousseau e o cristianismo. Há, pelo menos, dois grupos de estudiosos que resolveram enfrentar essa problemática: os que desconsideram os vínculos entre Rousseau e o cristianismo e os que defendem continuidades entre um outro.

Por exemplo, pesquisadores como Ward (2013) baseada no capítulo sobre a "Religião civil" da obra "Do Contrato Social" sustenta que há rupturas entre Rousseau e o cristianismo, já que o genebrino defenderia uma proposta de secularização da religião em vista da unidade do corpo político que forma o contrato. Ruzza (2012) apresenta o deísmo de Rousseau na forma da religião natural e civil quase sem nenhum vínculo com o cristianismo, o que preconiza, em nosso entendimento, a superação da religião cristã. Maritain (1970) assegura que o cristianismo de Rousseau é discutível, já que o genebrino o reduz ao conceito

3 Sobre as insípidas interpretações de Voltaire sobre os judeus, sugerimos a leitura do trabalho de Bucci (2009). Segue referência: BUCCI, Eugênio. Intolerância, ou a tragédia do não-diálogo. In: Adauto Novaes (org.). Vida vício virtude. São Paulo: Editora Senac, 2009, 212-217.

4 Para Ruzza (2012, p. 251), a finalidade do deísmo é a de: "substituir a preocupação pela ortodoxia com uma religião natural e tolerante; a busca do bem transcendental pela felicidade eterna; a espera passiva da providência pela dedicação a sociedade, pela participação às coisas da política e pela expectativa do progresso liderado pelo homem. Isso é possível se rejeitarmos a nossa responsabilidade no pecado original, se revalorizamos a natureza humana e os seus direitos naturais, se confiamos no uso da razão aliada às práticas da experimentação, contra a revelação e a tradição".

\begin{tabular}{|l|l|l|l|l|}
\hline Ronita Dialectus & Ano 8 & n. 15 & Agosto - Dezembro 2019 & p. 232 - 252 \\
\hline
\end{tabular}


de natureza, portanto, sem nenhum traço sobrenatural (graça divina). É o que Maritain (1970, p. 142) considera como sendo "A naturalization of Christianity".

Numa via contrária, há os estudiosos que defendem continuidades entre o cristianismo e Rousseau como parte integrante das suas ideias morais e políticas. Por exemplo, Gliozzo (1971) não limita o pensamento de Rousseau ao deísmo, como Ruzza (2012) tende a fazê-lo. Para Gliozzo (1971), deísmo, teísmo e cristianismo podem ser parte do complexo pensamento religioso do genebrino: “O Deísmo era somente o primeiro passo na organização da religião de Rousseau, pois os últimos incluiriam o teísmo com reminiscências do cristianismo" $"$.

Ao contrário de Ward (2013), Almeida Júnior (2008) não entende que o conceito de religião civil esteja em dicotomia com o cristianismo como um todo. Ele demarca bem a diferença entre cristianismo enquanto parte de igrejas históricas instituídas e o cristianismo universal. Para Almeida Júnior (2008), faz-se necessário ir além dos registros impressos no “Contrato Social”, já que, limitados apenas ao capítulo sobre a "Religião civil”, teríamos uma compreensão insuficiente do "teísmo cristão" de Rousseau.

Rousseau afirmou sua fé em Jesus Cristo, sua devoção pelo cristianismo e seu amor pelo Evangelho diversas vezes em seus escritos. Em carta ao pastor Paul-Claude Moultou, Rousseau (1972, p. 196) afirma: "Senhor, eu sou de uma religião tolerante por princípio, já que eu sou cristão. Eu tolero tudo, exceto a intolerância, pois toda inquisição me é odiosa" $"$. Desafiando as autoridades genebrinas quando da condenação de suas obras: "Do Contrato Social" e "Emílio ou Da Educação", Rousseau (2006), nas "Cartas escritas da montanha" afirma que ninguém mais do que ele se referiu com mais probidade sobre o cristianismo verdadeiro, já que alguns dos seus escritos - "Resposta ao Rei da Polônia", “Carta a D’Alembert", "Nova Heloísa”, "Emílio ou Da Educação" - demonstram “[...] o mesmo amor pelo Evangelho, a mesma veneração por Jesus Cristo" (ROUSSEAU, 2006, p. $262-263)^{7}$.

Essas continuidades, contudo, devem ser compreendidas com cautela, conforme sugere Kawauche (2013). Para Kawauche (2013, p. 223), do ponto de vista político há uma “abordagem prática” de Rousseau que visava encontrar uma solução para as relações entre as

5 Deism was only the first in classifying Rousseau's religion, for the latter included theism with reminiscences of Christianity (GLIOZZO, 1971, p. 279) (Tradução livre).

6 Mon cher, je suis dans ma Réligion tolerant par principles, car je suis chrétien; Je tolere tout, hors l'intolérance; mais toute inquisition m'est odiéuse (ROUSSEAU, Correspondance complète de Jean Jacques Rousseau, XV) (Tradução livre).

7 ROUSSEAU, O. C. III, p. 767-768.

\begin{tabular}{|l|l|l|l|l|}
\hline Q Rovista Dialectus & Ano 8 & n. 15 & Agosto - Dezembro 2019 & p. $232-252$ \\
\hline
\end{tabular}


religiões e o Estado, muito mais essenciais do que uma discussão envolta das declarações de fé cristã proferidas pelo genebrino. A nossa posição é de que há continuidades entre as ideias de Rousseau e o cristianismo, embora não seja possível afirmar que, por isso, suas ideias são absolutamente cristãs. Podemos dizer que Rousseau foi sensível a determinadas orientações cristãs, contudo, somos categoricamente céticos em considerar que o cristianismo ofereça alguma unidade ao pensamento de Rousseau.

\section{II}

Pelo menos três perguntas nos são necessárias para entendermos o cristianismo no período do Século das Luzes: o que se sabia, de fato, sobre Jesus Cristo? Jesus Cristo fundou o cristianismo? Como o cristianismo se desenvolveu ao longo da história? É de se considerar que as narrativas bíblicas eram compreendidas pela grande maioria dos cristãos como relatos históricos indiscutíveis, uma vez que eram parte da Revelação divina. Em outras palavras, a Bíblia era considerada como um livro de história, e não apenas como narrativas recheadas de acontecimentos fantásticos que expressavam a fé de um povo.

Dessa forma, para os cristãos, toda a Bíblia convergia para os eventos em volta da personagem de Jesus Cristo. Ele era a ponte que interligava o Antigo ao Novo Testamento - a Antiga e a Nova Aliança - além disso, Jesus era o fundamento de todo o cristianismo desenvolvido ao longo dos séculos. Conforme Mitchell (1993, p. 07):

Quando se fala da história Bíblica os reais eventos são ambos demarcados pelos dois Testamentos: a Criação, a queda de Adão, a fé de Abraão, a Aliança de Moisés com Deus, a primeira vinda de Cristo, a Redenção, etc. $\mathrm{O}$ acontecimento preeminente da história bíblica é, portanto, a primeira vinda de $\mathrm{Cristo}^{8}$.

Voltaire não se limitou a investigar o cristianismo através da sequência de narrativas que a Bíblia oferecia, nas quais, como vimos, iam da Criação a Jesus Cristo, de Jesus Cristo à Igreja primitiva. Esse bloco dava continuidade entre o Antigo e o Novo Testamento. Embora na obra "O túmulo do fanatismo", o foco de Voltaire seja discutir historicamente o judaísmo e o cristianismo, temos que deixar claro que, em seus trabalhos, ele tem uma concepção abrangente de história. Concepção esta que não se limita a examinar apenas este ou aquele credo em particular.

8 When speaking of biblical history, the real events are those delineated by the two Testaments; Creation, Adam's fall, Abraham's faith, Moses' covenant with God, Christ's first coming, the Redemption, etc. The preeminent event of biblical history for Christians is, of course, Christ's first coming (Tradução livre).

Q Povista Dialectus
Ano 8

n. 15


Assim, para não sermos arbitrários no recorte sobre o cristianismo na ótica desse pensador francês, torna-se necessário ressaltar que essa religião não ocupa espaço único e definitivo das suas atenções. A história do cristianismo é parte específica da análise de Voltaire sobre a "trajetória da civilização", e não apenas isso, o cristianismo faz parte da história deteriorada dessa mesma civilização. Conforme Souza (2001, p. 114):

\begin{abstract}
Em primeiro lugar, a história é para Voltaire a trajetória da civilização, entendida aqui como o conjunto dos desenvolvimentos produzidos pelo homem nas artes, nas ciências, nas técnicas, e, além disso, das transformações espirituais e morais que acompanharam esses desenvolvimentos. Em princípio, esta trajetória linear tem uma direção definida, que seria a realização, nas sociedades humanas, dos valores estabelecidos pela razão. Trata-se, portanto, de uma visão intelectualista e cultural da história humana. Contudo, não há de antemão nenhuma garantia de que esta trajetória se realize de maneira regular, muito menos de que os fins racionais sejam necessariamente atingidos. As recaídas na barbárie sempre podem acontecer.
\end{abstract}

Nesse caso, entendemos que o percurso histórico na concepção de Voltaire era cambiante, devido às "recaídas" resultantes de obscurantismos e barbáries que assediavam os costumes dos povos ao longo da história. A história do cristianismo é página discutível em todo esse processo. Os costumes e crenças judaicos e cristãos se inserem em um contexto bem posterior na história das religiões. Na verdade, Voltaire sugere que não havia nada de novo nesses costumes e crenças mencionados. Provavelmente para fazer o contraponto com a teologia preponderante, ele tenha optado por uma concepção diferente de investigar a história partindo de narrativas criadas por povos e civilizações bem anteriores à cultura judaica e cristã:

Dois povos pareciam contribuir para abalar a crença na cronologia da História Sagrada: os egípcios, cujos documentos falavam de dinastias de milhares de anos, e os chineses, que teriam existido antes da data que os cristãos atribuíam a Adão (SOUZA, 2001, p. 120).

Portanto, quando Voltaire analisa o cristianismo, ele o analisa inserido dentro de uma visão abrangente da história das religiões. Talvez ele tenha agido assim para promover uma interpretação não proeminente dessa religião revelada. Não são poucas as relações construídas por Voltaire que associam o judaísmo e o cristianismo à intolerância e ao fanatismo. Muito embora, no "Tratado sobre a tolerância", Voltaire insiste em demonstrar que

\begin{tabular}{|l|l|l|l|l|}
\hline Q Povista Dialectus & Ano 8 & n. 15 & Agosto - Dezembro 2019 & p. 232 - 252 \\
\hline
\end{tabular}


havia também histórias e relatos que demonstram uma apreciação pela tolerância por parte de judeus e cristãos.

O que se sabia sobre Jesus Cristo era baseado em narrativas advindas pelos evangelhos “oficiais" (Mateus, Marcos, Lucas e João), cada um com suas peculiaridades ao apresentar aspectos da vida, da morte e da ressurreição de Jesus Cristo. Havia ainda as narrativas apócrifas não reconhecidas pela imensa maioria das igrejas cristãs.

Voltaire não faz tanta distinção entre os evangelhos oficiais e as narrativas consideradas apócrifas. Havia um ambiente intelectualmente hostil ao cristianismo, sobretudo ao cristianismo católico no século XVIII. Voltaire entende que os escritos sobre Jesus são narrativas com retoques visionários, testemunhos de gente simples (ignorante, às vezes fanática). Portanto, não devem ser consideradas registros históricos factíveis.

A graça e a fé que iluminaram a leitura das sagradas escrituras feitas por Agostinho e Pascal foram substituídas pela razão iluminista. Os encantos em volta das narrativas bíblicas capazes de estimular a imaginação das pessoas são empobrecidos. Para Souza (2001, p. 131): “Assim, o relato bíblico perde todo o privilégio e toda sacralidade e é reduzido à mesma natureza dos relatos das mitologias dos outros povos da Antiguidade". Por escaparem ao domínio da razão não se sabia ao certo o que era real e o que era ficção nessas narrativas. Desse modo, a Sagrada Escritura, incluindo os Evangelhos e o Novo Testamento nos quais continham as narrativas sobre Jesus e a Igreja primitiva, não eram confiáveis. Essa "genealogia" do cristianismo tinha como um dos objetivos questionar a influência política e moral das igrejas nas sociedades da época.

Portanto, reconstituir a "verdadeira" história do cristianismo a partir do judaísmo e da personagem de Jesus de Nazaré não foi uma atitude movida por uma mera curiosidade filosófica. O que estava também em jogo era o domínio político e, consequentemente, o poder coercitivo, que as igrejas exerciam sobre aquelas sociedades. Pelo menos é essa perspectiva que almejamos investigar nesse artigo. A política mantém um vínculo essencial com o poder. E quando este é exercido sob o julgo de autoridades políticas e religiosas, a situação se torna mais complexa, conforme citação: “A ambição de dominar os espíritos é uma das mais fortes paixões. Um teólogo, um missionário, um partidarista quer conquistar como um príncipe; e há muito mais seitas no mundo do que soberanias" (VOLTAIRE, 2006, p. 5) ${ }^{9}$.

Daí que provavelmente uma das questões centrais criadas pelos descontentes era: como essa situação toda foi originada? Obviamente, era necessária uma investigação

9 VOLTAIRE, O. C. Mélanges, p. 1001-1002.

\begin{tabular}{|c|c|c|c|c|}
\hline Revista 2 indectus & Ano 8 & n. 15 & Agosto - Dezembro 2019 & p. $232-252$ \\
\hline
\end{tabular}


histórica sobre o provável fundador do cristianismo, Jesus de Nazaré. Aspectos relacionados ao nascimento de Jesus, seus milagres e sua ressurreição, são rigorosamente questionados. Voltaire, por exemplo, nos apresenta registros nos quais salienta uma historicidade tosca associada a virtudes que norteiam a personagem de Jesus. Em "O túmulo do fanatismo", esse pensador francês escreve que

\begin{abstract}
Jesus é evidentemente um camponês grosseiro da Judeia, mais esperto sem dúvida, que a maioria dos habitantes do seu cantão. Sem saber, ao que tudo indica, nem ler nem escrever, quis formar uma pequena seita para se opor à dos recabitas, dos judaítas, dos terapeutas, dos essênios, dos fariseus, dos saduceus, dos herodianos: pois tudo era seita entre os infelizes judeus, desde o seu estabelecimento em Alexandria (VOLTAIRE, 2006, p. 51) ${ }^{10}$.
\end{abstract}

Evidentemente, não há qualquer traço de divindade nesse Jesus de Voltaire. De acordo com a citação, Voltaire sugere que esse rústico homem quis criar uma seita com o intuito de opor-se às seitas de seu contexto. Jesus era um judeu como qualquer outro e, assim, se envolvia com as mesmas bagatelas. No "Tratado sobre a tolerância", Voltaire (2000) apresenta um tom mais ameno mesclado a uma admiração para com a personagem de Jesus Cristo. O intuito de Voltaire é o demonstrar que Jesus, de acordo com os evangelhos, foi, acima de tudo, exemplo de caridade, indulgência e humanidade. Portanto, o "espírito da intolerância" não pode se utilizar de pequenos pretextos da vida de Jesus para incitar a violência. Afinal, o próprio Jesus "[...] morre vítima da inveja. Se ousarmos comparar o sagrado com o profano, e um Deus com um homem, sua morte, humanamente falando, tem muita semelhança com a de Sócrates" (VOLTAIRE, 2000, p. 87) ${ }^{11}$.

Voltaire defende a ideia segundo a qual Jesus nunca teve a intenção de fundar o cristianismo, portanto não pode haver conexão entre um acontecimento e outro. Em o "Catecismo do homem honesto", Voltaire (2011, p. 293) salienta que "o cristianismo, ao contrário, é em tudo diferente da religião de Jesus. Esse Jesus, filho de um carpinteiro de aldeia, jamais escreveu nada. E, provavelmente, ele não sabia nem ler, nem escrever" ${ }^{12}$. Não há indícios que Jesus estava preocupado em reunir crentes para tomar o poder, ou mesmo usar da violência e da sedição com o intuito de fomentar uma resistência política, uma vez que a Judeia de seu tempo era uma província subjugada ao Império Romano.

$10 \quad$ Id. ibid., p. 1029.

11 VOLTAIRE, O. C. Mélanges, p. 616.

12 VOLTAIRE, O. C. Mélanges, p. 662.

\begin{tabular}{|l|l|l|l|l|}
\hline Rovista 2 ialectus & Ano 8 & n. 15 & Agosto-Dezembro 2019 & p. $232-252$ \\
\hline
\end{tabular}


Ainda assim, esses registros sobre Jesus não justificam a conexão entre cristianismo e poder político desenvolvidos ao longo da história. O que eles nos dizem a partir de Voltaire é que a pessoa de Jesus não teve influência direta no desenrolar da história do cristianismo. A justificativa encontra-se em outra ordem de acontecimentos, conforme o "Catecismo do homem honesto":

\begin{abstract}
Um homem de uma imaginação forte se faz seguir por algumas pessoas de uma imaginação fraca. O rebanho aumenta; o fanatismo começa; a velhacaria completa. Um homem poderoso chega; ele vê uma multidão que pôs uma sela nas próprias costas e um freio na boca; ele monta nela e a conduz. Uma vez que a nova religião é aceita pelo Estado, o governo não está mais ocupado senão em proscrever todos os meios pelos quais ela foi estabelecida (VOLTAIRE, 2011, p. 300) ${ }^{13}$.
\end{abstract}

Há que se notar que o cristianismo como poder político não foi imposto pela força. Voltaire se refere a palavras como "imaginação", "rebanho", "fanatismo", "velhacaria". Se a política guarda um vínculo essencial com o poder, este, nos moldes de um "Estado cristão", não é natural, portanto é artificial. Isso sugere, para Voltaire um consentimento tácito, ou melhor, passivo, por parte de uma multidão cega que põe na própria boca um freio e nas costas o fardo da dominação. Assim, ela está pronta para ser manipulada.

É certo para esse pensador francês que houve um vácuo entre a religião de Jesus e o cristianismo primitivo e entre o cristianismo primitivo e a religião cristã; esta desenvolvida posteriormente sob a proteção do poder político dos imperadores romanos. Não apenas Jesus não teria sido o seu autor, mas também, se ele vivesse nos tempos modernos seria um militante contrário a todo o poder político que concentrava cristianismo e poder.

Voltaire contesta a veracidade das fontes da patrística que divulga as narrativas heroicas dos mártires supostamente vítimas das perseguições dos romanos. Os romanos são interpretados como algozes e os corajosos cristãos que defenderam a sua fé encarando a violência e o martírio, são apresentados como vítimas, tal qual Jesus o foi.

Sendo coerente com o seu método de investigação da história baseado na interpretação racional das narrativas, Voltaire não podia aceitar gratuitamente a interpretação eclesiástica que se fundava num encantando heroísmo vitimizado dos santos mártires. Às vezes, Voltaire eleva essas narrativas ao ridículo ao afirmar em "O túmulo do fanatismo":

13 Id. ibid., p. 665.

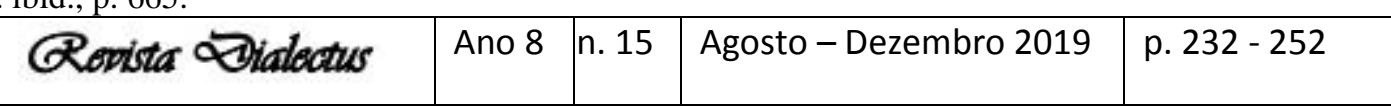


Que dizer da conversa de Inácio com o imperador Trajano, que lhe disse: Quem és tu, espírito impuro? E da bem-aventurada Sinforosa, que foi denunciada ao imperador Adriano por seus deuses lares? E de Policarpo, que as chamas de uma fogueira não ousaram tocar, mas que não pôde resistir ao gume do gládio? E do calçado da mártir santa Epipódia, que curou um cavalheiro da febre? (VOLTAIRE, 2006, p. 110) ${ }^{14}$.

Afinal, de acordo com essa interpretação, a Igreja aumentou sua influência e poderio junto ao Império Romano divulgando essas narrativas supersticiosas em meio à ignorância e inocência de bárbaros e cidadãos romanos: "Esses contos-da-carochinha me desagradam; não falarei mais deles”, afirma Voltaire (2006, p. 113) ${ }^{15}$. Tais fábulas foram responsáveis por subjugar todo um Império aos pés de uma religião. Ainda assim, esse pensador francês reconhece a existência de suplícios envolvendo cristãos em seus primeiros séculos. Contudo, esses suplícios existiram em decorrência não da violência dos romanos, mas sim da intolerância dos cristãos: "Reconheço que de fato alguns cristãos foram supliciados em diversas épocas, como sediciosos que tiveram a insolência de ser intolerantes e de insultar o governo. Receberam a coroa do martírio e fizeram por merecê-la" (VOLTAIRE, 2006, p. 113) ${ }^{16}$.

É por isso que Voltaire sustenta a ideia segundo a qual os romanos eram tolerantes ao passo que os judeus e cristãos é que eram intolerantes. Para Voltaire, a intolerância cristã contra outras seitas e religiões era uma afronta ao poder político vigente. Isso justifica a reação das autoridades romanas contra aqueles que sediciosamente causavam balbúrdia no Império. Afinal, para Voltaire, brigas e arengas estão na genética das religiões judaica e cristã.

Concluindo esse tópico, as reflexões de Voltaire deram sustentação à separação entre religião cristã e Estado. Refazendo a "genealogia" do cristianismo, Voltaire, questionando certezas inabaláveis por parte dos cristãos, insiste que pouco se sabe sobre a história de Jesus. Os Evangelhos "oficiais" e "apócrifos", se constituem parte de uma narrativa confusa, sustentada por fantasias e "milagres", e que, se levada a sério do ponto de vista histórico, dá suporte a superstições e fanatismos.

Os costumes e crenças judaicos e cristãos não apresentam quase nada de inédito, sendo, portanto, adaptações de crenças e narrativas de outros povos anteriores: egípcios, assírios, fenícios, caldeus, civilizações mais desenvolvidas que a "horda de árabes ladrões"

14 VOLTAIRE, O. C. Mélanges, p. 1066.

15 Id. ibid., p. 1068.

16 Id. ibid.

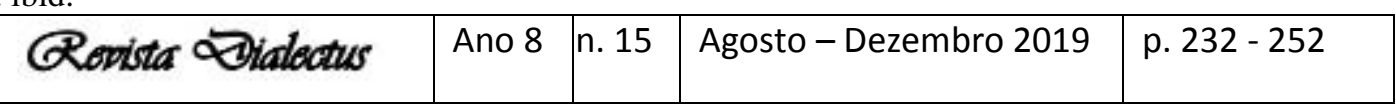


(VOLTAIRE, 2006, p. 17) ${ }^{17}$. Não há argumentos suficientes que atestam uma continuidade entre o judaísmo e Jesus como "Messias" e entre este e as igrejas cristãs. Assim como não há argumentos suficientes que atestam que Jesus criou dogmas e a doutrina cristã.

Na verdade, o cristianismo floresceu em um terreno pantanoso, confuso, em meio a um caldeirão de acontecimentos que reuniam seitas e suas superstições, fanatismos, imperadores tiranos como Constantino, hordas bárbaras e clérigos sedentos de poder, fanáticos e astutos. Conforme Ruzza (2012, p. 264):

\footnotetext{
Para Voltaire, o resto da História (o crescimento e o triunfo do Cristianismo) deve ser interpretado como um jogo político, com a Igreja se alinhando ao poder constituído (o Império Romano e depois os reinos bárbaros, como francos e normandos), com vantagens mútuas para os dois.
}

A fantasiosa mensagem cristã foi persuasiva aos ouvintes da desorientada plebe: "[...] uma canalha abjeta dirigia-se a uma populaça não menos desprezível” (VOLTAIRE, 2006, p. 66) ${ }^{18}$. O cristianismo foi se degenerando e se corrompendo à medida que os cristãos se alinharam ao poder político. A doutrina e os dogmas, nunca proferidos por Jesus e construídos em meio a sedições, querelas e disputas que fomentaram a intolerância religiosa, deram maior veracidade à crença. Ainda que Voltaire guardasse um certo respeito pelo cristianismo reformado, a discutível história do cristianismo teria sido fundada em meio à superstição, fanatismo e intolerância que resultou nos estreitos vínculos entre seus líderes e o poder político.

\section{III}

Rousseau também dedica um lugar para o cristianismo em algumas de suas obras inclusive àquelas inseridas no domínio da história. Contudo, devemos deixar claro que Rousseau desconsidera uma abordagem limitada a uma "teologia da história". Conforme Souza (2001, p. 67): "Para o cristianismo, o lugar lógico a partir do qual se discutem os problemas cosmológicos e humanos é Deus, e não o mundo". Observando o "Primeiro Discurso $^{19 "}$ e o "Segundo Discurso ${ }^{20 "}$ de Rousseau, se percebe que a discussão proposta pelo

17 Id. ibid., p. 17, O. C. Mélanges, p. 1009.

18 Id. ibid., p. 1038-1039.

19 ROUSSEAU, Jean-Jacques. Discurso sobre as ciências e as artes. São Paulo: Nova Cultural, 1983 (Os Pensadores), p. 329-352. O. C. III, p. 1-30.

20 ROUSSEAU, Jean-Jacques. Discurso sobre a origem e os fundamentos da desigualdade entre os homens. São Paulo: Nova Cultural, 1983 (Os Pensadores), p. 227-282. O. C. III, p. 109-194.

\begin{tabular}{|l|l|l|l|l|}
\hline Ronita Dialectus & Ano 8 & n. 15 & Agosto-Dezembro 2019 & p. 232 - 252 \\
\hline
\end{tabular}


cristianismo é como um todo, estranha. Os cristãos veem a história com esperança: da criação ao pecado; deste à redenção em Jesus Cristo; de Cristo à salvação.

A análise de Souza (2001) demonstra que Rousseau entende a história como “queda", "declínio", portanto, não há tanto lugar para a esperança. Observando os dois "Discursos", não há muito espaço para a salvação dos costumes degenerados e estabelecimentos políticos pela ação de Deus: “A história dos homens é história da queda. Esta transformação da alma humana corresponde à transformação das instituições, cuja trajetória também se dá no sentido que vai da pureza antiga à depravação atual” (Souza, 2001, p. 71). Daí que aproximar categoricamente o cristianismo à história em Rousseau, não é tarefa simples.

Por exemplo, os registros sobre as conexões entre história e cristianismo são escassos, no "Primeiro Discurso". Dentro das civilizações antigas mencionadas - Egito, Grécia, Roma, China -, a Judeia é ignorada, assim como o cristianismo primitivo e medieval. Jesus Cristo não está na galeria dos honoráveis cidadãos, como Sócrates e Fabrício. O Deus dos cristãos terá que aguardar a narrativa do "Fragmento alegórico" 21 e o livro IV do "Emílio ou Da Educação" para ganhar notoriedade. Em outras palavras, no "Primeiro Discurso", o cristianismo é desconsiderado. Essa religião ganhará destaque nos escritos que estão no entorno das discussões relacionadas ao "Primeiro Discurso", como é o caso da "Resposta ao rei da Polônia".

No "Primeiro Discurso", Rousseau estabelece uma conexão entre o progresso das ciências e das artes e a decadência dos costumes de povos e civilizações. Na ocasião, o rei da Polônia pretende refutar esse escrito de Rousseau. Uma das refutações, a que Rousseau considera "uma acusação mais grave", diz respeito ao auxílio que as ciências e as artes prestam à fé cristã. Indignado, Rousseau recorre à "história" e aos "fatos" para manter seu ponto de vista, segundo o qual a "simplicidade sublime do Evangelho" e a "doutrina de Jesus Cristo" foram aviltadas pelas especulações feitas por "homens frívolos"22 (ROUSSEAU, $1983 \mathrm{a}^{23}$, p. 381-382).

Contrariando Voltaire, Rousseau estabelece vínculos entre a história do povo hebreu - o povo eleito por Deus -, Jesus Cristo e os primeiros cristãos. Nesse itinerário, o

21 ROUSSEAU. Carta a Christophe de Beaumont e outros sobre a religião e a moral. São Paulo: Estação Liberdade, 2005, p. 204-214, O. C. IV, p. 1044-1054.

22 ROUSSEAU, O. C. III, p. 44.

23 Quando a letra "a" vier após a data, refiro-me à obra "Resposta ao rei da Polônia", quando vier a letra "b" após a data refiro-me à obra "Do Contrato Social". Essas obras encontram-se na tradução de Rousseau apresentada pela coleção "Os Pensadores" (ver referências).

\begin{tabular}{|l|l|l|l|l|}
\hline Gonita 2 ialectus & Ano 8 & n. 15 & Agosto-Dezembro 2019 & p. $232-252$ \\
\hline
\end{tabular}


foco central de Rousseau é o de demonstrar o quão são incompatíveis as ciências e a filosofia para a pureza da religião cristã. Assim, questões relacionadas ao que se sabia de fato sobre Jesus Cristo, e se ele fundou o cristianismo, não são colocadas, pois parece que são respostas evidentes para Rousseau. O registro que podemos encontrar diz respeito à atuação de Cristo e dos primeiros cristãos, e o desenvolvimento do cristianismo ao longo da história, nesse pequeno registro.

Nele, Jesus Cristo despreza a ciência e o estudo, ao contrário dos saduceus que são "os filósofos de Jerusalém" e os fariseus que são qualificados como "grandes hipócritas" e doutores da cidade. Após a morte de Cristo, a missão de "instruir e converter o mundo" foi confiada à gente simples, pobres artesãos e pescadores, gente que Voltaire não dava muito crédito. Os seguidores de Jesus convertiam as pessoas pelo exemplo de vida, conforme Rousseau (1983a, p. 382): “[...] pregavam sem arte, mas com o coração comovido, e, de todos os milagres com os quais Deus honrava sua fé, o mais impressionante era a santidade de sua vida; seus discípulos seguiram esse exemplo e o sucesso foi prodigioso"24. A narrativa é favorável ao cristianismo primitivo, sem dúvida.

Contudo, o cenário muda de aspecto, pois a narrativa ganha contornos em volta a conflitos, tramas e calúnias. O principal motivo é que “os padres pagãos" ficaram preocupados devido à queda das oferendas o que poderia comprometer a saúde do Estado e, por isso, foram se queixar junto aos príncipes. O resultado da aliança entre esses "padres" e os príncipes foi a perseguição aos cristãos. Atitude esta que produziu efeito contrário uma vez que os martírios produziram mais e mais conversões. Então, não satisfeitos, os "padres" recorreram a uma nova aliança, desta vez com os filósofos, com o intuito de caluniar os cristãos. O motivo é interessante, pois os filósofos se uniram aos "padres pagãos" já que o cristianismo não lhes oferecia vantagens.

Há uma incompatibilidade entre o cristianismo e a filosofia. Contudo, ao contrário de Voltaire para quem a filosofia seria antídoto contra o fanatismo e a intolerância dos cristãos, Rousseau toma o partido do cristianismo em suas origens, contra a filosofia. Além disso, Rousseau dá crédito aos mártires, algo que Voltaire duvidava, como vimos. Nessa breve narrativa de Rousseau, as conexões com o poder político são muito mais evidentes pelo lado dos líderes religiosos pagãos do que pelo lado cristão.

Em continuidade com a lógica do "Primeiro Discurso", Rousseau quer demonstrar que há contrastes entre o cristianismo de um lado, ciências, artes e filosofia, de outro. Pois,

$24 \quad$ Id. ibid., p. 45.

\begin{tabular}{|c|c|c|c|c|}
\hline Revista Alalectus & Ano 8 & n. 15 & Agosto - Dezembro 2019 & p. $232-252$ \\
\hline
\end{tabular}


tudo começa a mudar de aspecto quando os cristãos passaram a utilizar os recursos da filosofia e da teologia para defenderem e esclarecerem sua fé. No entanto, a simplicidade do Evangelho foi deturpada pelos dogmas, fruto das especulações dos cristãos, o que culminou em disputas violentas, perseguições e injúrias que contaminaram essa religião ao longo dos séculos: "Só Deus sabe quando terminarão todos esses males", lastima Rousseau (1983a, p. $385)^{25}$.

Se na "Resposta ao Rei da Polônia", Rousseau se dedica a escrever uma pequena, mas suave história do cristianismo, as relações entre o cristianismo e o poder político serão mais contundentes na obra: "Do Contrato Social", no capítulo sobre a "Religião civil" presente no livro IV. Nesse capítulo, o tratamento que Rousseau dá ao cristianismo é bem mais elaborado e complexo. Desse modo, povo nenhum, inclusive os judeus, é considerado "Povo eleito". Isso sugere que as religiões são criações das sociedades políticas e são analisadas por Rousseau numa perspectiva histórica linear. Pelo menos um tipo de religião predominava nas sociedades até o estabelecimento do cristianismo por Jesus: era a religião do cidadão.

Ela tem como vantagem encorajar uma unidade sagrada entre o súdito e o Estado a ponto de aquele abrir mão de sua própria vida por amor à pátria e estimular a obediência as leis. Contudo, fundada em superstições e crendices, a religião do cidadão manipula os súditos do Estado tornando-os intolerantes e sanguinários para com todos aqueles que não acreditam em seus deuses. Para Rousseau (1983b, p. 141), “isso põe tal povo num estado natural de guerra com todos os demais, situação essa muito prejudicial à sua própria segurança” ${ }^{26}$.

O que essas sociedades políticas antes do cristianismo têm em comum é a unidade entre as mesmas e as religiões, cada uma diferente para cada Estado diferente. A consequência é que a intolerância também era ao mesmo tempo teológica e civil. Como Rousseau sugere que os conflitos entre essas sociedades eram permanentes, povos vencidos eram obrigados a submeter-se aos deuses e religiões dos vencedores. Exceção aos judeus, pois, nos tempos da dinastia dos reis da Síria e Babilônia, eles não se submeteram aos seus deuses quando essas dinastias subjugaram a Palestina. É o início das perseguições nas quais apenas judeus e, posteriormente, cristãos sofreram em defesa de sua religião. Essa interpretação de Rousseau mais uma vez contrasta a de Voltaire.

25 Id. ibid., p. 48.

26 ROUSSEAU, O. C. III, p. 465.

\begin{tabular}{|l|l|l|l|l|}
\hline Rovista Dialectus & Ano 8 & n. 15 & Agosto - Dezembro 2019 & p. 232 - 252 \\
\hline
\end{tabular}


É assim que o nascimento do cristianismo com Jesus acontece em meio a uma universalização do paganismo dentro do Império Romano. Jesus e o cristianismo nascente inauguram uma nova fase, já que o estabelecimento de um "reino espiritual" desvinculou a religião da política. O resultado disso "[...] fez com que o Estado deixasse de ser uno e determinou as divisões intestinas que jamais deixaram de agitar os povos cristãos" (ROUSSEAU, 1983b, p. 139) ${ }^{27}$. Têm-se início a era da "religião do homem" ou o cristianismo, não o do tempo de Rousseau, como ele mesmo afirma, mas o do Evangelho. Em suas origens, era uma religião que renunciava a qualquer ambição política ou desejo por vantagens mundanas, pois os cristãos viviam nesse mundo não em função dele, mas para uma nova vida após a morte.

Para Rousseau, esse estilo de vida não convenceu os pagãos, pois, desconfiados, acreditavam que a renúncia a este mundo para ascender a outro além deste, era parte de um pretexto dos cristãos com vistas a usurparem o poder. Isso não tardou a acontecer, conforme Rousseau (1983b, p. 139) ${ }^{28}$ :

O que os pagãos temiam aconteceu e, então, tudo mudou de aspecto. Os humildes cristãos mudaram de linguagem e logo se viu esse pretenso reino do outro mundo tonar-se neste, sob um chefe visível, o mais violento despotismo.

Essas contradições que estão no âmago dos vínculos entre cristianismo e poder político não deixaram de ser questionadas por Rousseau. Nesse aspecto, o genebrino aproxima esse violento despotismo sob a autoridade de um chefe à "religião do padre", que é o terceiro tipo de religião na qual se inclui, além do cristianismo romano, a religião dos lamas e dos japoneses. Há uma afinidade com Voltaire, uma vez que este tem certa admiração com o cristianismo reformado em detrimento do cristianismo romano. A religião do padre é também parte de uma depravação do cristianismo.

Rousseau identifica vantagens e inconvenientes no cristianismo do Evangelho. Ele qualifica esse cristianismo como uma: “[...] religião santa, sublime e verdadeira, os homens, filhos do mesmo Deus, reconhecem-se todos como irmãos, e a sociedade que os une não se dissolve nem com a morte" (ROUSSEAU, 1983b, p. 141) ${ }^{29}$. Por isso, não há espaço para a intolerância ou mesmo ambição pelo poder por parte dos cristãos nesse tipo de religião. $\mathrm{O}$ problema reside na necessária identidade que essa religião por sua própria natureza não

27 Id. ibid., p. 462.

28 Id. ibid.

29 Id. ibid., p. 465.

\begin{tabular}{|l|l|l|l|l|}
\hline Ronista Dialectus & Ano 8 & n. 15 & Agosto-Dezembro 2019 & p. $232-252$ \\
\hline
\end{tabular}


promove entre os cristãos e o Estado, uma vez que "[...] longe de ligar os corações dos cidadãos ao Estado, desprende-os, como de todas as coisas da terra. Não conheço nada mais contrário ao espírito social" (ROUSSEAU, 1983b, p. 141-142) ${ }^{30}$. Como observa Moscateli (2010, p. 230), um Estado formado por súditos verdadeiramente cristãos seria presa fácil para tiranos e conquistadores internos ávidos de poder, além de que a caridade não permitiria que os cristãos matassem o inimigo que, vindo do estrangeiro, pusesse em risco a soberania do Estado.

Para superar os inconvenientes da religião do cidadão e do cristianismo do Evangelho, Rousseau propõe uma "profissão de fé puramente civil" que encorajasse "sentimentos de sociabilidade" entre os cidadãos e os súditos. Rousseau propõe dogmas daquilo que ele chama de religião civil para tornar coeso o corpo político e combater a intolerância. Os dogmas são subdivididos em positivos, quais sejam: "A existência da Divindade poderosa, inteligente, benfazeja, providente e provisora; a vida futura; a felicidade dos justos; o castigo dos maus; a santidade do contrato e das leis". E um dogma negativo: “[...] a intolerância, que pertence aos cultos que excluímos” (ROUSSEAU, 1983b p. 144)

Tona-se difícil um cristão verdadeiro se comprometer com os dois últimos dogmas, já que ele não se engajaria verdadeiramente com a "santidade do contrato e das leis" uma vez que, como vimos, os cristãos deveriam desprezar as coisas da terra. Por outro lado, o exercício da caridade impediria que um cristão verdadeiro martirizasse um súdito, mesmo sendo este declaradamente perverso. Então deveriam também os cristãos serem banidos ou martirizados se não obedecessem aos dogmas da religião civil? De fato, esse capítulo tornouse muito controverso para a mentalidade cristã.

Se os cristãos tiverem sede de poder político e criarem um Estado cristão motivados pela ambição, eles cairiam naquilo que Rousseau denominou de religião do padre, ou o cristianismo romano, ou ainda nos inconvenientes destacados na religião do cidadão. Seria um cristianismo falso. Por outro lado, um Estado composto por cristãos autênticos estaria em sérias dificuldades pois seria vulnerável a ameaças externas e internas. O exercício da caridade frearia qualquer atitude belicista dos cristãos. Verdadeiros cristãos não aceitariam o compromisso com o dogma da santidade do contrato e das leis, nem tampouco com o dogma da intolerância. O capítulo sobre a religião civil coloca os cristãos em uma situação cambiante quando pensamos nas relações entre essa religião e a política.

30 Id. ibid.

31 Id., ibid., p. 468-469.

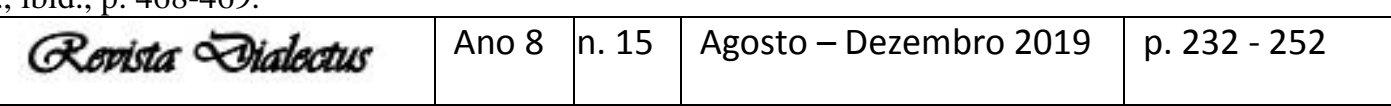


As controvérsias seguiram adiante, não apenas em solo católico, mas também em ambiente reformado uma vez que autoridades protestantes de Genebra condenaram a obra "Do Contrato Social", para não deixar de mencionar também a obra "Emílio ou da Educação". Mesmo Rousseau literalmente não incluindo o cristianismo reformado como parte integrante da religião do padre. A condenação das obras de Rousseau foi compilada nas: "Cartas escritas do campo"32, escritas anonimamente por Tronchin, Procurador Geral de Genebra, sendo dada também voz de prisão a Rousseau, caso ele pisasse em terras genebrinas. As acusações contra Rousseau tiveram como foco a suposta agressão ao cristianismo e sua relação com os governos:

\footnotetext{
"Meus livros são", dizem eles, "ímpios, escandalosos, temerários, cheios de blasfêmias e de calúnias contra a religião. Sob a aparência de dúvidas, o autor aí reuniu tudo que visa solapar, abalar e destruir os principais fundamentos da religião cristã revelada. Atacam todos os governos" (ROUSSEAU, 2006, p. 148) ${ }^{33}$.
}

Em resposta, Rousseau escreveu as “Cartas escritas da montanha”. Nela, além de querer defender suas obras das acusações, ele quer defender também sua própria dignidade e, porque não dizer, o seu próprio cristianismo? Ao referirmos ao cristianismo de Rousseau, não é nossa intenção defender afirmações apressadas tipo "Rousseau é cristão". Afinal, ele atacou ou pôs sob suspeição a eficácia de dogmas do cristianismo como a redenção, o pecado original e os milagres ${ }^{34}$. Coerente em seus argumentos apresentados no capítulo sobre a religião civil, Rousseau sustenta a tese segundo a qual o verdadeiro cristianismo não tem vínculo direto com o poder político, ou mesmo com qualquer Estado particular. A história mostra que o grande erro dos cristãos foi o de confundir os dois domínios, conforme citação:

Então, aqueles que quiseram fazer do cristianismo uma religião nacional e introduzilo como parte constitutiva do sistema de legislação cometeram, dessa forma duas faltas perniciosas, uma contra a religião, outra contra o Estado. Afastaram-se do espírito de Jesus Cristo, cujo reino não é deste mundo e, misturando aos interesses terrestres os da religião, contaminaram sua pureza celeste, transformando-a em arma dos tiranos e instrumento dos perseguidores (ROUSSEAU, 2006, p. 169) ${ }^{35}$.

32 ROUSSEAU, Jean-Jacques. Cartas escritas da montanha. In: A República genebrina. São Paulo: Unesp, 2006, p. 45.

33 ROUSSEAU, O. C. III, p. 689.

34 Sobre a temática envolvendo Rousseau e os milagres sugerimos a leitura do capítulo quarto de "Religião e Política em Rousseau", de Kawauche (2013, p. 232-244). Ver referências.

35 Id., ibid., p. 704.

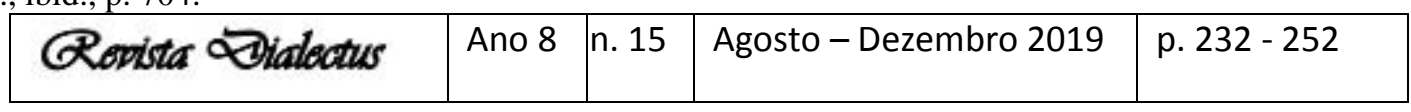


Em outras palavras, os cristãos que confundem a terra com o céu, por exemplo, os que confundem o poder político e as vantagens que ele proporciona com as orientações do Evangelho, não são cristãos autênticos, na interpretação de Rousseau. O genebrino identifica essa mesma situação em Genebra e adverte os seus acusadores genebrinos ao afirmar que

\begin{abstract}
a doutrina do Evangelho só tem um objeto: chamar e salvar todos os homens; a liberdade deles, seu bem-estar aqui na Terra, dela não fazem parte, Jesus disse isso mil vezes. Misturar a esse objeto opiniões terrestres é perturbar sua simplicidade sublime, é manchar sua santidade com interesses humanos: isso é verdadeiramente uma impiedade (ROUSSEAU, 2006, p. 173) ${ }^{36}$.
\end{abstract}

Não haveria erro algum em alguns pastores criticarem orientações seculares em "Emílio" ou em "Do Contrato Social", nas quais pusessem a fé cristã sob objeções secularizadas. Isso faria parte das duas orientações centrais da Reforma, quais sejam: “[...] reconhecer a Bíblia como regra de sua crença e não admitir outro intérprete do sentido da Bíblia além de si próprio" (ROUSSEAU, 2006, p. 181) ${ }^{37}$. O problema por parte desses líderes reformados está em confundir uma legítima crítica às opiniões diferentes das suas para revertê-la em difamações e punições de ordem política e civil.

Rousseau poderia cometer erros, colocar o cristianismo sob controvérsias, mas não que o genebrino quisesse com isso ridicularizar a religião cristã e suas igrejas. Foi assim que Rousseau foi acusado por Voltaire, conforme carta que este escreveu para à família D’Argental: "Ele [Rousseau] se queixa para Christophe [arcebispo de Paris] que é cristão ao mesmo tempo em que cumula a religião cristã de opróbrios e ridículos; há uma dúzia de páginas Sublimes contra esta Santa religião" (VOLTAIRE, apud ROUSSEAU, 1972, p. $107)^{38}$. Como vimos, Voltaire conhecia bem o assunto que se tratava de ridicularizar o cristianismo.

De novo, Rousseau reconhece que algumas de suas ideias já destacadas nesse trabalho poderiam pôr obstáculos à fé cristã e ele mesmo poderia errar ao propor essas ideias na ótica de teólogos e fanáticos. Contudo, isso não deveria deteriorar o conteúdo das suas obras. Se cristãos se levantassem contra suas opiniões e se servissem do aparelhamento do

36 Id., ibid., p. 706.

37 Id., ibid., p. 712-713.

38 Il proteste à Christophe qu'il est chretien, et en meme temps il couvre la religion chetienne d'opprobre et de ridicules; il y a une douzaine de pages Sublimes contre cette Sainte religion (ROUSSEAU, Correspondance complète de Jean Jacques Rousseau XVI) (Tradução livre).

\begin{tabular}{|l|l|l|l|l|}
\hline Ronita Dialectus & Ano 8 & n. 15 & Agosto - Dezembro 2019 & p. 232 - 252 \\
\hline
\end{tabular}


Estado para perseguir violentamente o autor e suas obras, isso, paradoxalmente revelaria que Rousseau está certo. O cristianismo estatizado é um mal e contraria as orientações do Evangelho. Rousseau põe os seus acusadores, que incluem padres católicos e pastores de Genebra na mesma vala, relegada a fanáticos e inquisidores. De fato, estes não seriam "verdadeiramente cristãos" como Rousseau se julgava ser.

O fato é que o cristianismo reformado de Genebra mostrou a sua face inquisitória a Rousseau, uma vez que em outros escritos - a "Dedicatória" do "Segundo Discurso", "Carta a D’Alembert” (ROUSSEAU, 2006, p. 39-40) - o autor de “ Do Contrato Social” não enxergou, ou não quis enxergar, tal fato. Rousseau fez um inventário da inquisição na Genebra reformada. Nesse aspecto, as relações perversas entre o cristianismo e o poder político ultrapassaram as fronteiras do catolicismo medieval e do catolicismo do Antigo Regime. É interessante que a história não é caminho para a redenção do cristianismo, mas para o seu "declínio" (Souza 2001), já que o verdadeiro cristianismo se encontra no passado, o cristianismo do presente está degenerado e Rousseau não dá nenhuma esperança aos cristãos de que o futuro do cristianismo será melhor. Ele tinha razão.

\section{Conclusão}

A análise comparativa que envolveu as relações entre cristianismo e poder no domínio histórico, a partir de algumas das ideias de Voltaire e Rousseau, trouxe luzes para algumas questões que agitaram e ainda agitam o cenário político. Podemos especificar os seguintes resultados: fé cristã e poder político não devem se fundir. Os "partidos cristãos" causam mais problemas do que soluções para a sociedade e, por isso, obstaculizam o caminho para a boa saúde do corpo político. Os líderes políticos não devem ser, acima de tudo, cristãos e suas medidas não devem confundir ambos os domínios: secular e confessional.

Atualmente, no Brasil, há grupos de igrejas cristãs, católicas e protestantes que contestam a confusão entre as esferas confessionais e seculares. Para esses grupos sensatos, o Estado é laico, e a religião teria outro papel nele, que não fosse de almejar o poder político. A religião deveria ter um papel mais humano, fraterno, que levasse as pessoas a um encontro autêntico com Deus. Por exemplo, em fins de setembro do ano passado, determinadas igrejas protestantes divulgaram uma "Carta pastoral para a nação brasileira" 39 .

39 “Carta pastoral à nação brasileira”. Centro nacional de fé e política Dom Helder Câmara - CEFEP, 10 de novembro de 2018.

\begin{tabular}{|c|c|c|c|c|}
\hline Q Rovista Dialectus & Ano 8 & n. 15 & Agosto - Dezembro 201 & p. $232-252$ \\
\hline
\end{tabular}


Essa "Carta" rejeita a construção de um "governo exercido em nome de Deus" e defende valores como a tolerância, a defesa dos mais pobres e a crítica a toda forma de violência e injustiça. Em um trecho marcante, a "Carta" afirma: "Nosso repúdio a toda e qualquer forma de instrumentalização da religião e dos espaços sagrados para promoção de candidatos e partidarismos". E acrescenta que: "Cremos num Deus grande o suficiente para não se deixar usar por formas anticristãs de pensamento e de ação" 40 .

As ideias de Voltaire e Rousseau atestam para a defesa de um Estado laico e de uma política livre do assédio de grupos cristãos. Como outrora, elas nos iluminam a resistir e acreditar que o caminho da política não é o do ódio, da violência e da intolerância, ainda que o poder político, por obscuras e estranhas forças, seja sempre ambicionado.

\section{REFERÊNCIAS:}

ALMEIDA JÚNIOR, José Benedito. A filosofia contra a intolerância: política e religião no pensamento de Jean-Jacques Rousseau. Tese de Doutorado em Filosofia. São Paulo, USP, Departamento de Filosofia, 2008.

GLIOZZO, Charles A. The Philosophes and Religion: Intellectual Origins of the Dechristianization Movement in the French Revolution. In Church History, v. 40, n. 3, 1971, p. 273-283.

KAWAUCHE, Thomas. Religião e política em Rousseau: o conceito de religião civil. São Paulo: Humanitas: FAPESP, 2013.

MARITAIN, Jacques. Three Reformers: Luther, Descartes, Rousseau. Washington: Kennikat Press, 1970.

MITCHELL, Joshua. Not By Reason Alone: Religion, History, and Identity in Early Modern Political Thought. Chicago: The University of Chicago Press, 1993.

MOSCATELI, Renato. Rousseau frente ao legado de Montesquieu: história e teoria política no século das luzes. Porto Alegre: EDIPUCRS, 2010.

ROUSSEAU, Jean-Jacques. Carta a D'Alembert. Tradução de Roberto Leal Ferreira. Campinas, SP: Unicamp, 1993.

Cartas escritas da Montanha. Tradução de Maria Constança Peres Pissarra e Maria das Graças de Souza. São Paulo: Unesp, 2006.

Correspondance complète de Jean Jacques Rousseau. Bunbary, 1972 (The Voltaire Foundation) (XV-XVI).

Fontes, 1999.

Emílio ou Da Educação. Tradução de Roberto Leal Ferreira. São Paulo: Martins

40 Id. ibid.

\begin{tabular}{|c|c|c|}
\hline Rovista Dialectus & Ano 8 & n. 1 \\
\hline
\end{tabular}


Hucitec, 1994.

Júlia ou a Nova Heloísa. Tradução de Fulvia M. L. Moretto. Campinas, SP: II-V).

Oeuvres Complètes. Bibliothèque de la Plêiade. Paris: Gallimard, 1959 - 1995, (v.

Várias Obras. 3. ed. Tradução de Lourdes Santos Machado. São Paulo: Nova Cultural, 1983 (Os Pensadores).

RUZZA, Antonio. Em nome das luzes: um desafio à religião. São Paulo: Anablume, 2012.

SOUZA, Maria das Graças de. Ilustração e história: o pensamento sobre a história no Iluminismo francês. São Paulo: Discurso Editorial, 2001.

VOLTAIRE, François Marie Arouet. Catecismo do homem honesto. Tradução de Regina Schöpke e Mauro Baladi (Orgs.). Filosofia Clandestina: vol. 2. São Paulo: Martins Fontes, 2011.

Mélanges. Paris: Gallimard, 2002.

2006.

O túmulo do fanatismo. Tradução de Claudia Berliner. São Paulo: Martins Fontes,

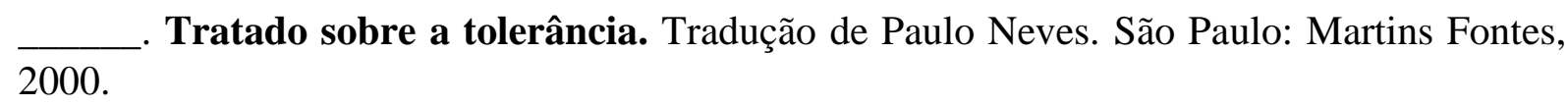

WARD, Frances. Why Rousseau was Wrong? Christianity and the Secular Soul. London: Bloomsbury, 2013. 